Patients in the Bamenda Health District of Cameroon: A Cross-sectional Study", Cardiology and Therapy, 6, pp. 53-67.

6. Ibrahim M., Mahmoud H. (2012), "Compliance with treatment of patients with hypertension in Almadinah Almunawwarah: A communitybased study", Journal of Taibah University Medical Sciences, 7 (2), pp. 92-98.
7. Michel B., Brent M E. (2019), "Adherence in Hypertension; A Review of Prevalence, Risk Factor, Impact, and Management", Circulation Research, 124 (7).

8. Niriayo Y. L., Ibrahim S., Kassa T. D., et al. (2019), "Practice and predictors of self-care behaviors among ambulatory patients with hypertension in Ethiopia", PLoS One, 14 (6), pp. e0218947.

\title{
KIỂU HÌNH KHÒ KHÈ Ở TRẺ EM DƯớI 5 TUỔI TẠI QUẢNG NINH
}

\section{TÓM TẮT}

Khò khè là triêu chứng thường găp ở trẻ em. Kiểu hình khò khè khác nhau gây nên bởi nguyên nhân khác nhau. Đối tượng và phương pháp: Nghiên cứu được tiến hành tại khoa Nhi bệnh viện Bãi Cháy và khoa nội nhi bệnh viện Sản Nhi Quảng Ninh trên 164 bệnh nhân dưới 5 tuổi vào viện vì khò khè trong giai đoạn từ 01/07/2020 đến 30/06/2021. Mục tiêu: Mô tả kiểu hình khò khè ở trẻ em dưới 5 tuổi tại tỉnh Quảng Ninh. Kết quả: Tỷ lệ trẻ khởi phát khò khè sớm (trước 12 tháng tuổi), trung gian (từ 12 đến 24 tháng tuổi), muộn (sau 24 tháng đến 60 tháng) lần lượt là $77,4 \% ; 17,7 \%$ và $4,9 \%$. Trong đó, nhóm trẻ dưới 12 tháng chiếm tỷ lệ 57,9\%. Có 54,9\% trẻ dưới 5 tuổi có ít nhất 2 đợt khò khè. Khò khè từng đợt do virus hay gặp ở nhóm dưới 12 tháng, chiếm tỷ lệ $46 \%$, khò khè nhiêu yếu tố khởi phát gặp ở nhóm trên 12 tháng chiếm tỷ lệ $80 \%$. Có mối liên quan giữa số đợt khò khè với tiên sử di ứng của bản thân và gia đình, tiền sử tiếp xúc với khói thuốc lá $(p<0,05)$. Nguyên nhân khò khè hay gặp nhất ở nhóm dưới 12 tháng là viêm tiểu phế quản chiếm tỷ lệ $74,7 \%$. Nhóm 25 đến 60 tháng nguyên nhân hay gặp là hen phế quản chiếm tỷ lệ 87,5\%. Kết luận: Kiêu hình khò khè khác nhau trong các nhóm bênh lý khác nhau

Từ khóa: kiểu hình khò khè, trẻ em

\section{SUMMARY}

\section{WHEEZING PHENOTYPES IN CHILDREN UNDER 5 YEARS OF AGE IN QUANG NINH PROVINCE}

Wheezing is a common symptom which is often seen in children. The different wheezing phenotypes are caused by a variety of diseases. Materials and methods: This study was conducted in 164 children under 5 years of ages hospitalized due to wheezing at the Pediatric Department of Bai Chay Hospital and Internal Medicine Pediatrics Department of Quang Ninh Obstetrics and Children's Hospital, from July $1^{\text {st }}$,

\footnotetext{
1,2Bênh viện Đa khoa Bãi cháy

${ }^{2}$ Trường Đại học Y Hà Nội

Chịu trách nhiệm chính: Nguyễn Thị Huyền

Email: drnguyenhuyen82@gmail.com

Ngày nhân bài: 3.5.2021

Ngày phản biện khoa học: 30.6.2021

Ngày duyệt bài: 6.7.2021
}

\section{Nguyễn Thị Huyền ${ }^{1,2}$, Nguyễn Thị Diệu Thúy ${ }^{2}$}

2020 to June $30^{\text {th }}, 2021$. Objectives: To describe the wheezing phenotypes of children under 5 years of age in Quang Ninh province. Results: The prevalence of early onset of wheeze (before 12 months of age), intermediate (from 12 to 24 months of age), and late (after 24 months to 60 months) was $77.4 \% ; 17.7 \%$ and $4.9 \%$ respectively. $57.9 \%$ of wheezing ocured in children under 12 month. In addition, $54.9 \%$ of children under 5 ages had at least 2 episodes of wheeze. Episodic viral wheeze was common in the children under 12 month group, accounting for $46 \%$ wheares multitrigger wheeze was common in children over 12 month group, accounting for $80 \%$. There were a statistically associated between the frequency of wheezing and personal and family history of allergies, second hand smoke exposure in children with wheezing $(p<0.05)$. The most common cause of wheezing in the group under 12 month was bronchiolitis, accounted for $74.7 \%$. In the group of 25 to 60 months, the common cause was asthma, accounted for $87.5 \%$. Conclusion: Wheezing phenotypes are different in different diseases.

Keywords: Wheezing phenotype, children

\section{I. ĐẶT VẤN ĐỀ}

Khò khè là triệu chứng thường gặp ở trẻ em. Gần $50 \%$ trẻ em bị khò khè trong năm đâu đời, $20 \%$ sẽ tiếp tục bi triệu chứng khò khè trong những năm tiếp theo ${ }^{1}$. Khò khè ít khi biểu hiện đơn độc mà thường kết hợp với các triệu chứng hô hấp khác như ho, tức ngực, thở nhanh và/hoặc khó thở... tùy thuộc vào nguyên nhân gây ra khò khè. Nhiêu bố mẹ khi thây trẻ khò khè tái diễn thường nghĩ rằng đó là triệu chứng của hen phế quản. Tuy nhiên, tình trạng khò khè có thể được cải thiện và biến mất theo thời gian ở nhiều trẻ em. Vì vậy, xác định kiểu hình khò khè đã được nghiên cứu nhằm phân loại và tiên đoán khả năng phát triển thành bệnh hen phế quản trong tương lai². Mặc dù khò khè là triệu chứng thường gặp ở trẻ nhỏ, hay gây lo lắng cho gia đình bệnh nhân và thây thuốc nhưng cách tiếp cận với trẻ bị khò khè là một thách thức đối với các nhà lâm sàng, đặc biệt là các thây thuốc nhi khoa từ việc chẩn đoán tới điêu trị và tiên lượng. Thêm nữa, một số thăm dò nhằm tìm 
hiểu nguyên nhân gây khò khè khó thực hiện ở trẻ em như đo chức năng hô hấp, đo pH thực quản.... Tỉnh Quảng Ninh là một tỉnh có ngành than khoáng sản phát triển mạnh nhất trong cả nước. Hiện nay, tại tỉnh chưa có một nghiên cứu nào đánh giá về mô hình khò khè ở trẻ em cũng như các nguyên nhân gây khò khè, vì vậy nghiên cứu được tiến hành với mục tiêu mô tả một số kiểu hình khò khè, nguyên nhân gây khò khè thường gặp ở trẻ dưới 5 tuổi tại Quảng Ninh.

\section{II. ĐỐI TƯợNG VÀ PHƯƠNG PHÁP NGHIÊN CỨU \\ 1. Đối tượng}

Tiêu chuẩn chọn: - Các bệnh nhi dưới 5 tuổi có triệu chứng khò khè, được khẳng định triệu chứng khò khè bởi bác sỹ nhi khoa, được điều trị nội trú tại khoa nhi bệnh viện Bãi Cháy và khoa nội nhi bệnh viện Sản Nhi Quảng Ninh từ 01/07/2020 đến 30/06/2021

- Cha me hoặc người chăm sóc trẻ đồng ý tham gia và tuân thủ quy trình nghiên cứu.

Tiêu chuẩn loại trừ. Bệnh nhi khò khè có kèm theo di chứng bệnh lý thần kinh-cơ

2. Phương pháp nghiên cứu: Nghiên cứu mô tả cắt ngang

3. Cỡ mẫu: Mẫu thuâan tiện, tất cả bệnh nhân đáp ứng tiêu chuẩn lựa chọn

4. Đạo đức nghiên cứu. Đề cương nghiên cứu đã được thông qua hội đồng đạo đức nghiên cứu y sinh học - Trường đại học y Hà nội. (quyết định số 454/ GCN-HDDĐNCYSH-ĐHYHN). Nghiên cứu này chỉ nhằm mục đích nâng cao hiệu quả khám chữa bệnh, ngoài ra không có mục đích nào khác. Các số liệu và thông tin trong nghiên cứu trung thực, chính xác.

\section{KẾT QUẢ NGHIÊN CứU}

3.1 Đặc điểm chung của đối tượng nghiên cứu. Trong thời gian nghiên cứu từ tháng 7/2020 đến tháng 6/2021 có 164 bệnh nhân đủ tiêu chuẩn nghiên cứu. Tuổi nhập viện trung vị là 9 tháng. Nhóm trẻ dưới 12 tháng chiếm tỷ lệ $57,9 \%$. Tỷ lệ nam/nữa là $1,7 / 1$ $(p<0,05)$

3.2 Đặc điểm kiểu hình khò khè ở trẻ dưới 5 tuổi

Bảng 1. Phân loại khò khè theo thời gian khởi phát

\begin{tabular}{|c|c|c|c|}
\hline \multicolumn{2}{|c|}{ Thời điểm khò khè so lượng } & $\mathbf{n}$ & $\%$ \\
\hline \multirow{2}{*}{$\begin{array}{c}\text { Khò khè } \\
\text { khởi phát sớm }\end{array}$} & $\leq 6$ th & 90 & 54,9 \\
\hline & $7^{\text {th }}-11^{\text {th }}$ & 37 & 22,6 \\
\hline \multicolumn{2}{|c|}{$\begin{array}{l}\text { Khò khè khởi phát trung gian } \\
\left(12^{\text {th }}-24^{\text {th }}\right)\end{array}$} & 29 & 17,7 \\
\hline \multicolumn{2}{|c|}{ Khò khè khởi phát muộn $\left(25^{\text {th }}-60^{\text {th }}\right)$} & 8 & 4,9 \\
\hline & & 164 & 100 \\
\hline
\end{tabular}

Nhân xét: Tuổi khởi phát khò khè hay gặp nhất là nhóm dưới 12 tháng chiếm tỷ lệ $77,5 \%$.

Bảng 2. Kiểu hình khò khè theo nhóm tuổi

\begin{tabular}{|c|c|c|c|c|c|c|}
\hline \multicolumn{3}{|c|}{ Đăc điểm Nhóm tuối } & $<12$ th & $12-24$ th & $25-60$ th & $\mathbf{p}$ \\
\hline \multicolumn{3}{|c|}{ Số ngày khò khè trung bình } & $6,64 \pm 2,21$ & $7,50 \pm 2,37$ & $6,63 \pm 2,60$ & 0,161 \\
\hline \multirow{4}{*}{$\begin{array}{l}\text { Số đợt } \\
\text { khò khè }\end{array}$} & \multirow{2}{*}{ Khò khè lần đầu } & $\mathrm{n}$ & 64 & 6 & 4 & \multirow{4}{*}{0,0001} \\
\hline & & $\%$ & 86,5 & 8,1 & 5,4 & \\
\hline & \multirow{2}{*}{ Khò khè $\geq 2$ lần } & $\mathrm{n}$ & 31 & 28 & 31 & \\
\hline & & $\%$ & 34,4 & 31,2 & 34,4 & \\
\hline \multirow{4}{*}{$\begin{array}{l}\text { Yếu tố } \\
\text { khởi phát }\end{array}$} & \multirow{2}{*}{$\begin{array}{l}\text { Khò khè từng đợt } \\
\text { sau nhiếm virus }\end{array}$} & $\mathrm{n}$ & 23 & 13 & 14 & \multirow{4}{*}{0,036} \\
\hline & & $\%$ & 46,0 & 26,0 & 28,0 & \\
\hline & \multirow{2}{*}{$\begin{array}{c}\text { Khò khè nhiêu yếu tố } \\
\text { khới phát }\end{array}$} & $\mathrm{n}$ & 8 & 15 & 17 & \\
\hline & & $\%$ & 20,0 & 37,5 & 42,5 & \\
\hline
\end{tabular}

Nhận xét: Khò khè từng đợt sau nhiễm virus xuất hiện nhiều hơn ở nhóm <12 tháng tuối $(46,0 \%)$, so với hai nhóm $12-24$ tháng tuổi $(26,0 \%)$ và $25-60$ tháng tuổi $(28,0 \%)$. Khò khè nhiều yêuu tố khởi phát chủ yếu ở nhóm trên 12 tháng. Sự khác biệt có ý nghĩa thống kê $(p<0,05)$.

Bảng 3. Một số yếu tố liên quan đến số đợt khò khè

\begin{tabular}{|c|c|c|c|}
\hline \multicolumn{2}{|c|}{ Yếu tố } & Số đợt khò khè $x \pm$ SD & $\mathbf{p}$ \\
\hline \multirow{2}{*}{$\begin{array}{c}\text { Tiền sử dị ứng của gia } \\
\text { đình }\end{array}$} & Có & $3,84 \pm 4,14$ & \multirow{2}{*}{0,0001} \\
\hline & Không & $1,97 \pm 2,27$ & \\
\hline \multirow{2}{*}{$\begin{array}{c}\text { Tiền sử dị ứng của bản } \\
\text { thân }\end{array}$} & Có & $5,49 \pm 5,961$ & \multirow{2}{*}{0,0001} \\
\hline & Không & $2,28 \pm 1,95$ & \\
\hline \multirow{2}{*}{ Tiếp xúc khói thuốc lá } & Có & $3,84 \pm 4,68$ & \multirow{2}{*}{0,003} \\
\hline & Không & $2,65 \pm 2,89$ & \\
\hline \multirow{2}{*}{ Tiếp xúc với vật nuôi } & Có & $3,50 \pm 2,53$ & \multirow{2}{*}{0,420} \\
\hline & Không & $2,90 \pm 3,72$ & \\
\hline
\end{tabular}


VIETNAM MEDICAL JOURNAL N01 - AUGUST - 2021

\begin{tabular}{|c|c|c|c|}
\hline \multirow{2}{*}{ Đẻ non } & Có & $2,84 \pm 1,34$ & \multirow{2}{*}{0,831} \\
\cline { 2 - 4 } & Không & $3,03 \pm 3,75$ & \multirow{2}{*}{0,659} \\
\cline { 2 - 4 } Cân nặng & $\leq 2500 \mathrm{gr}$ & $3,32 \pm 3,46$ & $2,96 \pm 3,57$ \\
\hline
\end{tabular}

Nhân xét: Những bênh nhân có tiền sử gia đình di ứng, tiền sử bản thân di ứng hoăcc tiếp xúc với khói thuốc lá có số đợt khò khè nhiều hơn nhóm không có tiền sử. Sự khác biệt có ý nghĩa thống kê $(p<0,05)$.

Bảng 4. Nguyên nhân gây khò khè theo nhóm tuổi

\begin{tabular}{|c|c|c|c|c|c|c|c|c|c|}
\hline Nhóm tuối & \multicolumn{2}{|c|}{$<12$ th } & \multicolumn{2}{|c|}{$12-24$ th } & \multicolumn{2}{|c|}{$25-60$ th } & \multicolumn{2}{|c|}{ Tống } & \multirow[b]{2}{*}{$\mathbf{p}$} \\
\hline Bênh & $\mathbf{n}$ & $\%$ & $\mathbf{n}$ & $\%$ & $\mathbf{n}$ & $\%$ & $\mathbf{n}$ & $\%$ & \\
\hline VTPQ & 56 & 74,7 & 19 & 25,3 & 0 & 0,0 & 75 & 100 & \multirow{5}{*}{0,0001} \\
\hline Hen phế quản & 0 & 0,0 & 3 & 12,5 & 21 & 87,5 & 24 & 100 & \\
\hline Viêm phối & 38 & 71,7 & 9 & 17 & 6 & 11,3 & 53 & 100 & \\
\hline Khác & 0 & 0,0 & 2 & 20,2 & 8 & 80 & 10 & 100 & \\
\hline Bất thường bấm sinh & 1 & 50,0 & 1 & 50,0 & 0 & 0,0 & 2 & 100 & \\
\hline
\end{tabular}

Nhận xét: Nguyên nhân khò khè thường gặp ở lứa tuối dưới 12 tháng chủ yều là viêm tiếu phế quản chiếm tỷ lệ 74,7\%, hen phế quản thường gặp ở lứa tuổi trên 24 tháng tuổi chiếm tỷ lệ 87,5\%. Bất thường bẩm sinh được phát hiện lứa tuổi dưới 24 tháng.

\section{BÀN LUÂN}

Khò khè là âm thanh có âm sắc cao phát ra từ ngực trong suốt thì thở ra. Khò khè là một trong dấu hiệu của sự tắc nghẽn đường hô hẩp dưới ${ }^{1}$. Nghiên cứu được thực hiện trên 164 trẻ từ 1tháng đến 60 tháng có triệu chứng khò khè nhập viện. Tỷ lệ trẻ khởi phát khò khè sớm (trước 12 tháng tuổi), trung gian (từ 12 đến 24 tháng tuổi), muộn (sau 24 tháng đến 60 tháng) lần lượt là $77,4 \% ; 17,7 \%$ và 4,9\%. Có sự khác biệt về phân bố tỷ lệ khởi phát khò khè ở các nhóm tuổi trong nghiển cứu của chúng tôi so với Nguyễn Thị Hà và Hoàng Thị Thanh Mai tại Hà Nội ${ }^{3,4}$. Tỷ lệ khởi phát khò khè trước 12 tháng của chúng tôi cao hơn so với tỷ lệ $66 \%$ và $74,5 \%$ của hai tác giả trên. Nguyên nhân do các tác giả chỉ nghiên cứu trên đối tượng khò khè dai dẳng là tái diễn.

Về kiểu hình khò khè, Hội Hô hấp châu Âu năm 2008 đã phân loại khò khè dựa trên kiểu hình lâm sàng: khò khè từng đợt do virus và khò khè nhiều yếu tố khởi phát ${ }^{5}$. Khò khè từng đợt do virus chỉ xuất hiện trong từng đợt bệnh, giữa các đợt trẻ không có triệu chứng. Khò khè nhiều yếu tố khởi phát không chỉ xuất hiện trong những đợt cấp mà triệu chứng còn tồn tại giữa các đợt, các yếu tố khởi phát là virus đường hô hấp, dị nguyên, vận động, khói thuốc. Trong nghiên cứu của chúng tổi, khò khè từng đợt do virus chiếm tỷ lệ $55,6 \%$ ở tất cả các nhóm tuổi. Nhóm tuổi hay gặp nhất là dưới 12 tháng, chiếm tỷ lệ $46 \%$. Tỷ lệ khò khè nhiều yếu tố khởi phát là chiếm tỷ lệ 44,4\%. Nhóm tuổi hay gặp nhất trong khò khè nhiều yếu tố khởi phát là nhóm trên 12 tháng chiếm tỷ lệ $80 \%$.
Theo Leonard và cộng sự, các yếu tố nguy cơ liên quan đến kiểu hình khò khè ở trẻ em sống ở thành thị là tiếp xúc khói thuốc lá trước sinh, me căng thẳng hoặc trầm cảm, hệ vi sinh vật và dị nguyên trong bụi nhà ${ }^{6}$. Nghiên cứu của Luis và cộng sự về các yếu tố nguy cơ khò khè trong năm đầu đời ở 28687 trẻ sơ sinh sống ở các nước phát triển và đang phát triển, các yếu tố nguy cơ của khò khè là cảm lạnh trong 3 tháng đầu đời, đi học mẫu giáo, giới nam, me hút thuốc khi mang thai, tiền sứ gia đình dị ứng (hen, viêm mũi dị ứng), tiền sử bản thân dị ứng (viêm da cơ địa) ${ }^{7}$. Hai nghiên cứu này có kết quả tương đồng so với kết quả nghiên cứu của chúng tôi là có mối liên quan giữa số đợt khò khè với tiền sử di ứng của bản thân và gia đình, tiền sử tiếp xúc với khói thuốc lá. Chúng tôi chưa ghi nhận được mối liên quan giữa số đợt khò khè và tiền sử đẻ non, cân nặng thấp như nghiên cứu của Agnes và cộng sự .

Trong nghiên cứu của chúng tôi, nguyên nhân khò khè hay gặp nhất ở nhóm dưới 12 tháng là viêm tiểu phế quản, nhóm 25 đến 60 tháng nguyên nhân thường gặp là hen phế quản.

\section{KẾT LUẦN}

Kiểu hình khò khè khác biệt theo nhóm nguyên nhân và theo nhóm tuổi, vì vậy cần hỏi bệnh, thăm khám lâm sàng tỉ mỉ, đề xuất cận lâm sàng phù hợp hỗ trợ để chẩn đoán chính xác nguyên nhân gây khò khè.

Lời cảm ơn. Chúng tôi xin chân thành cảm ơn bệnh nhi và gia đình trẻ đã tham gia, hợp tác tốt trong quá trình nghiên cứu. Xin cảm ơn Khoa Nhi bệnh viện Bãi Cháy và khoa nội nhi bệnh viện Sản Nhi Quảng Ninh đã tạo điều kiện thuận 
lợi để nhóm nghiên cứu có thể thu thập số liệu và hoàn thành nghiên cứu.

\section{TÀI LIỆ THAM KHẢO}

1. Martinez FD, Wright $A L$, Taussig $L M$, et al. Asthma and wheezing in the first six years of life. The Group Health Medical Associates. N Engl ] Med. 1995; 332(3): 133-138. doi:10.1056/NEJM199501193320301

2. Spycher BD, Silverman $M$, Kuehni CE. Phenotypes of childhood asthma: are they real? Clin Exp Allergy. 2010;40(8):1130-1141. doi:10.1111/j.1365-2222.2010.03541.x

3. Hoàng Thị Thanh Mai. Nghiên cứu môt số kiểu hình khò khè thường gặp ở trẻ dưới 5 tuổi tại bênh viện Nhi Trung Ương. Luận văn Bác sỹ nội trú, Trường Đai hoc Y Hà Nôi. 2018

4. Nguyến Thị Hà. Nghiên cứu nguyyên nhân khò khè ớ trẻ dưới 5 tuối tại khoa miến dịch-dị ứngkhớp bệnh viện Nhi Trung Ương. Luân văn Bác sỹ nội trú, Trường Đại học Y Hà Nội. 2013

5. Brand PLP, Baraldi E, Bisgaard $H$ et al.
Definition, assessment and treatment of wheezing disorders in preschool children: an evidence-based approach. Eur Respir J. 2008;32(4):1096-1110. doi:10.1183/09031936.00002108

6. Bacharier LB, Beigelman A, Calatroni $A$ et al. NIAID sponsored Inner-City Asthma Consortium. Longitudinal Phenotypes of Respiratory Health in a High-Risk Urban Birth Cohort. Am J Respir Crit Care Med. 2019;199(1):71-82. doi:10.1164/ rccm.201801-01900C

7. Garcia-Marcos L, Mallol J, Solé D, Brand PLP, EISL Study Group. International study of wheezing in infants: risk factors in affluent and non-affluent countries during the first year of life. Pediatr Allergy Immunol. 2010;21(5):878-888. doi:10.1111/j.1399-3038.2010.01035.x

8. Sonnenschein-van der Voort AMM, Arends LR, de Jongste JC et al. Preterm birth, infant weight gain, and childhood asthma risk: a metaanalysis of 147,000 European children. J Allergy Clin Immunol. 2014;133(5):1317-1329. doi:10.1016/ j.jaci.2013.12.1082

\section{KẾT QUẢ ỨNG DỤNG KỸ THUÂ̂T GIẢM ĐAU BẰNG PHÓNG BẾ KHOANG CẠNH SỐNG Ở BỆNH NHÂN CHẤN THƯƠNG NGỰC KÍN}

\section{TÓM TẮT}

Mục tiêu: Nhận xét chỉ định và đánh giá hiệu quả giảm đau của kỹ thuật phóng bế khoang cạnh sống trong điều trị người bệnh chấn thương ngực kín. Đối tượng và phương pháp: 73 bệnh chấn thương ngực kín điều trị tại Khoa Phẫu thuật lî̀ng ngực - Bệnh viện Quân Y 103, được giảm đau bằng phóng bế khoang cạnh sống. Thời gian từ 01/2018 đến 12/2020. Tiến cứu, mô tả. Kết quả: Tuổi trung bình $52,82 \pm 11,72$ (lớn nhất 92, nhỏ nhất 27). Tỷ lệ nam/nữ là 3,6/1. Nguyên nhân chủ yếu do tai nạn giao thông (58,9\%), tai nạn sinh hoạt $23,3 \%$ và tai nạn lao động $17,8 \%$. Giảm đau bằng phóng bế khoang cạnh sống được chỉ định khi có gãy từ 3 xương sườn trở lên, ở cùng một bên lồng ngực (100\%); 39,7\% trường hợp có gã̃y xương kết hợp, gồm: xương đòn cùng bên (26,0\%), xương bả vai cùng bên $(12,3 \%)$ và xương châu $(1,4 \%)$. Điểm VAS khi nghỉ và khi ho tại các thời điểm lân lượt là: T0 là $6,6 \pm 0,9$ và $8,0 \pm 1,0 ; T 1$ là $5,1 \pm 0,9$ và $6,7 \pm 1,0 ; T 2$ là $4,1 \pm 0,9$ và $5,5 \pm 1,0 ; T 3$ là $3,2 \pm 0,9$ và $4,4 \pm 1,1 ; T 4$ là $2,5 \pm 0,8$ và $3,3 \pm 0,9$, xu hướng giảm có ý nghĩa thống kê $(p<0,05)$. Tỷ lệ biến chứng là 1,4\%. Kết luận: Phóng bế khoang canh sống cho người bệnh CTNNK gãy nhiêu xương sườn ở một bên lồng ngực an toàn, hiệu quả giảm đau tốt.

*Bệnh viện 103, Hoc viện Quân Y Chịu trách nhiệm chính: Vũ Anh Hải Email: vuanhhai.ncs@gmail.com Ngày nhận bài: 16/5/2021

Ngày phàn biện khoa hoc: 12/6/2021

Ngày duyệt bài: 10/7/2021

\section{Vũ Anh Hải*, Lê Việt Anh*}

Từ khóa: Giảm đau cạnh sống; chấn thương ngực kín; gãy xương sườn.

\section{SUMMARY}

\section{THE RESULTS OF THORACIC PARAVERTEBRAL BLOCK FOR PAIN MANAGEMENT IN PATIENTS WITH BLUNT CHEST TRAUMA}

Objectives: Review indications and evaluate the analgesic effectiveness of thoracic paravertebral block in the treatment of patients with blunt chest trauma. Subjects and methods: 73 blunt chest trauma treated at the Department of Thoracic Surgery Military Hospital 103 underwent pain relief by thoracic paravertebral block, from January 2018 to December 2020. Prospective, descriptive. Results: The mean age was $52.8 \pm 11.7(\max 92, \min 27)$. The male/female ratio was 3.6/1. Traffic accidents were the main cause $(58.9 \%)$, followed by daily-life accidents $(23.3 \%)$ and occupational accidents $(17.8 \%)$. The indication of pain relief by paravertebral block for patients who had fractured 3 or more ribs $(100 \%)$, on the same side of the chest; $39.7 \%$ of patients had combined fractures, including: ipsilateral clavicle $(26.0 \%)$, ipsilateral scapula $(12.3 \%)$ and pelvis $(1.4 \%)$. VAS scores at rest or coughing were recorded: T0 was $6.6 \pm 0.9$ and $8.0 \pm 1.0$; T1 was $5.1 \pm 0.9$ and $6.7 \pm 1.0$; T2 was $4.1 \pm 0.9$ and $5.5 \pm 1.0$; T3 was $3.2 \pm 0.9$ and $4.4 \pm 1.1$; T4 was $2.5 \pm 0.8$ and $3.3 \pm 0.9$, the decreasing trend was statistically significant $(p<0.05)$. The complication rate was $1.4 \%$. Conclusion: Thoracic paravertebral block for patients with multiple rib fractures on one side of the ribcage was safe and effective, with good analgesic effect. 